\title{
Aerosol-ozone correlations during dust transport episodes
}

\author{
P. Bonasoni ${ }^{1}$, P. Cristofanelli ${ }^{1}$, F. Calzolari ${ }^{1}$, U. Bonafè ${ }^{1}$, F. Evangelisti ${ }^{1}$, A. Stohl ${ }^{2}$, S. Zauli Sajani ${ }^{3}$, R. van Dingenen ${ }^{4}$, \\ T. Colombo ${ }^{5}$, and Y. Balkanski ${ }^{6}$ \\ ${ }^{1}$ National Research Council, Institute for Atmospheric Science and Climate, via Gobetti 101, 40129, Bologna, Italy \\ ${ }^{2}$ Cooperative Institute for Research in the Environmental Sciences, University of Colorado/NOAA Aeronomy Laboratory, \\ USA \\ ${ }^{3}$ Agenzia Regionale Prevenzione e Ambiente dell'Emilia-Romagna, Struttura Tematica Epidemiologia Ambientale, Modena, \\ Italy \\ ${ }^{4}$ Joint Research Center, Ispra, Italy \\ ${ }^{5}$ Ufficio Generale per la Meteorologia, Pratica di Mare, Roma, Italy \\ ${ }^{6}$ Laboratoire des Sciences du Climat et de l'Environment, Gif-Sur-Yvette Cedex, France
}

Received: 3 February 2004 - Published in Atmos. Chem. Phys. Discuss.: 16 April 2004

Revised: 14 July 2004 - Accepted: 27 July 2004 - Published: 3 August 2004

\begin{abstract}
Its location in the Mediterranean region and its physical characteristics render Mt. Cimone $\left(44^{\circ} 11^{\prime} \mathrm{N}\right.$, $10^{\circ} 42^{\prime} \mathrm{E}$ ), the highest peak of the Italian northern Apennines ( $2165 \mathrm{~m}$ asl), particularly suitable to study the transport of air masses from the north African desert area to Europe. During these northward transports 12 dust events were registered in measurements of the aerosol concentration at the station during the period June-December 2000, allowing the study of the impact of mineral dust transports on free tropospheric ozone concentrations, which were also measured at $\mathrm{Mt}$. Cimone. Three-dimensional backward trajectories were used to determine the air mass origin, while TOMS Aerosol Index data for the Mt. Cimone area were used to confirm the presence of absorbing aerosol over the measurement site.
\end{abstract}

A trajectory statistical analysis allowed identifying the main source areas of ozone and aerosols. The analysis of these back trajectories showed that central Europe and north and central Italy are the major pollution source areas for ozone and fine aerosol, whereas the north African desert regions were the most important source areas for coarse aerosol and low ozone concentrations. During dust events, the Mt. Cimone mean volume concentration for coarse particles was $6.18 \mu \mathrm{m}^{3} / \mathrm{cm}^{3}$ compared to $0.63 \mu \mathrm{m}^{3} / \mathrm{cm}^{3}$ in dust-free conditions, while the ozone concentrations were $4 \%$ to $21 \%$ lower than the monthly mean background values. Our observations show that surface ozone concentrations were lower than the background values in air masses coming from north Africa, and when these air masses were also rich in coarse particles, the lowest ozone values were registered. Moreover, preliminary results on the possible impact of the dust events on $\mathrm{PM}_{10}$ and ozone values measured in Italian urban

Correspondence to: P. Bonasoni

(p.bonasoni@isac.cnr.it) and rural areas showed that during the greater number of the considered dust events, significant $\mathrm{PM}_{10}$ increases and ozone decreases have occurred in the Po valley.

\section{Introduction}

Mineral dust is one of the greatest sources of natural aerosol and represents, with $2150 \mathrm{Tg} / \mathrm{yr}$, about $37 \%$ of the total production of atmospheric primary aerosols by both natural and anthropogenic sources (Penner et al., 2001). When the weather conditions are favourable to lift dust material, dust particles rising in the free troposphere can be transported over long distances by the atmospheric circulation. The presence of mineral dust in the atmosphere may contribute to climatic variations and influence the behaviour of some tropospheric trace gases, changing the oxidizing capacity of the atmosphere (Arimoto, 2001). Atmospheric aerosol can modify the energy balance through scattering and absorption of light (Sokolik and Toon, 1996). The radiative effect of mineral aerosol from natural sources and disturbed soils contributes about $8 \%$ to total aerosol scattering of incoming solar radiation (Andreae, 1995). In particular, those mineral aerosol particles, which are characterised by very large surface area, can strongly absorb the shortwave solar radiation, influencing the radiative forcing of climate (Dickerson et al., 1997), or causing a photolysis rate reduction, thus inhibiting ozone production. In fact, in the lower atmosphere, mineral aerosol may strongly influence the balance of atmospheric trace gases, including ozone (Prospero et al., 1995; Dentener and Crutzen, 1993; Zhang et al., 1994; Dickerson et al., 1997). Dentener et al. (1996) in their modelling studies, suggested that the ozone destruction on mineral aerosol 
surfaces could lead to a $10 \%$ reduction of $\mathrm{O}_{3}$ concentrations in the dust source areas. In fact, the large surface area of solid dust particles may play a significant role as a reactive surface on which heterogeneous chemistry can take place (Schmitt et al., 1988; Zhang et al., 1994). Recently, from a global modelling study, Bauer et al. (2004) have found out that during the year 2000 a decrease in global tropospheric ozone mass by about $5 \%$ could be due to the heterogeneous reactions on dust aerosol. Hanisch and Crowley (2003) have shown that the ozone loss can be due to decomposition, catalytic destruction or absorption on mineral oxides.

In order to find out whether air masses coming from the Sahara carry depleted $\mathrm{O}_{3}$ concentrations during their travel towards or passage over the European continent, it would be necessary to know the ozone concentration in the desert source areas. Unfortunately, due to the lack of measurement sites in these areas the actual concentrations of background $\mathrm{O}_{3}$ in the African deserts are not known. Only few measurements in the Lybian desert (Gusten et al., 1996), in Chad and Tunisia (Fabian and Pruchniewicz, 1977) were carried out in the past. Fabian and Pruchniewicz (1977) found that the lowest $\mathrm{O}_{3}$ concentrations were associated with air masses coming from Central Africa, while Gusten et al. (1996), in spite of the limited measurement period (18 days), highlighted an interesting phenomenon. During their measurements, carried out in the western Lybia desert (30 km south of the Oasis of Dukhla), relatively small $\mathrm{O}_{3}$ diurnal variations ranging between 45 and 50 ppbv were registered when northerly winds prevailed. On the contrary, under southerly winds coming from the desert, very low $\mathrm{O}_{3}$ concentrations with a diurnal variation between 25 and 45 ppbv were measured (Gusten et al., 1996). Outside the African deserts, but close to the west coast of north Africa, trace gas measurements, carried out at the Izaña baseline mountain station (Canary Islands), showed marked surface ozone depletions during Saharan dust events (Prospero et al., 1995; Schmitt et al., 1998), which significantly influenced the annual mean ozone concentrations (Schmitt et al., 1998; de Reus et al., 2000).

Dust mobilisation over the African deserts supplies a large contribution to natural mineral aerosol in the atmosphere. Using the Total Ozone Mapping Spectrometer Aerosol Index (TOMS-AI), Prospero (1999) showed that the Sahara desert exports more dust than any other desert region. During dust storms, aerosol concentrations of more than $1000 \mu \mathrm{g} / \mathrm{m}^{3}$ (Ganor, 1994) can be injected into the atmosphere. Although a great part of this mineral aerosol moves westward into the Atlantic Ocean and towards the American continent, another considerable part can be transported across the Mediterranean basin towards Southern Europe and can occasionally even reach Central and Northern Europe (Franzen et al., 1994; Schwikowski et al., 1995; Moulin et al., 1998; Kubilay et al., 2000; Rodriguez et al., 2001). Ansmann et al. (2003) have recently documented the large spatial extent and three-dimensional structure of such a dust transport event using data from the European aerosol lidar net- work. Moulin (1997) estimated in his thesis that $70 \times 10^{6}$ tons of dust are transported annually over the Mediterranean and $350 \times 10^{6}$ tons of dust are transported over the Atlantic. This is in good agreement with work from Schütz (1980) and d'Almeida (1986) who estimated the north Atlantic transport at respectively 260 and $190 \times 10^{6}$ tons and the Mediterranean transport at $100 \times 10^{6}$ tons.

In Southern Europe, Mt. Cimone is one of the first high mountains that is passed by the Saharan air masses and where measurements of the chemical composition of the background atmosphere are regularly carried out. This has permitted to register several Saharan dust intrusions since 1991 (Bonasoni et al., 1996), showing that low ozone concentrations usually accompany these transport events. This fact was confirmed by soundings of ozone, humidity and temperature carried out in the lowland Po valley (Bonasoni et al., 1998). During the recent MINATROC EU project (Mineral Dust and Tropospheric Chemistry), in order to better characterize the influence of mineral aerosol on surface ozone concentration, high time resolution in situ measurements of surface ozone, aerosol size distribution and other parameters were carried out at Mt. Cimone from June to December 2000. This permitted to identify all the dust transport events reaching Mt. Cimone. The correlation between ozone concentration and coarse and fine aerosol was studied also using back-trajectory and satellite data analyses. Moreover, possible influence of Saharan dust transport on $\mathrm{PM}_{10}$ and ozone concentrations measured in urban and rural sites in the Po valley, has been also considered.

\section{Site, experimental procedures, and methods}

\subsection{Site and measurement description}

In order to investigate the relationship between trace gases and mineral aerosol in the free troposphere, an extended field campaign, with measurements of $\mathrm{O}_{3}$ and $\mathrm{PM}_{10}$, particle size and mass distribution and meteorological parameters, was carried out at the Mt. Cimone baseline station $\left(44^{\circ} 11^{\prime} \mathrm{N}\right.$, $10^{\circ} 42^{\prime} \mathrm{E}, 2165 \mathrm{~m}$ asl) from June to December 2000 . Mt. Cimone (MTC) is the highest mountain peak in the Northern Apennines. It is considered representative of the European continental background conditions (Fischer et al., 2003; Bonasoni et al., 2000) and due to its altitude $(2165 \mathrm{~m}$ asl) and geographical position $\left(44^{\circ} 11^{\prime} \mathrm{N}, 10^{\circ} 42^{\prime} \mathrm{E}\right)$ to the south of the Alps and the Po valley and to the north of the Mediterranean Sea, this measurement site is suitable to study a wide spectrum of atmospheric processes. Particularly, the Apennines are the first mountain chain met by Saharan air masses on their way to Europe. Usually, dust transport events occur with strong synoptically forced south-westerly winds that, even during the summer season, prevent the development of the valley breeze wind regime, which could potentially bring locally polluted air masses up to MTC. In fact, 
Table 1. Saharan dust events recorded at MTC in the period June-December 2000. Travel Time represents the mean travel time of the air masses from north Africa coastline to Mt. Cimone. The hourly coarse peak value (the hourly minimum for ozone), the hourly mean value recorded during each event as well as the monthly mean concentration are reported for coarse aerosol particle (Coarse) and for de-trended ozone $\left(\mathrm{O}_{3}^{D E T}\right)$. Finally, the percentage differences $\left(\triangle \mathrm{O}_{3}^{D E T}\right)$ between the monthly $\mathrm{O}_{3}^{D E T}$ mean value and the hourly $\mathrm{O}_{3}^{D E T}$ minimum value are reported.

\begin{tabular}{|c|c|c|c|c|c|c|c|c|}
\hline \multirow[b]{2}{*}{ Event } & \multirow[b]{2}{*}{$\begin{array}{c}\text { Travel Time } \\
\text { (h) }\end{array}$} & \multicolumn{3}{|c|}{ Coarse concentration $\left(\mathrm{N} / \mathrm{cm}^{3}\right)$} & \multicolumn{3}{|c|}{$\mathrm{O}_{3}^{D E T}$ concentration (ppbv) } & \multirow[b]{2}{*}{$\begin{array}{c}\Delta \mathrm{O}_{3}^{D E T} \\
(\%)\end{array}$} \\
\hline & & $\begin{array}{c}\text { Peak value } \\
\text { during event }\end{array}$ & $\begin{array}{l}\text { Mean value } \\
\text { during event }\end{array}$ & $\begin{array}{c}\text { Monthly } \\
\text { mean value }\end{array}$ & $\begin{array}{c}\text { Minimum value } \\
\text { during event }\end{array}$ & $\begin{array}{l}\text { Mean value } \\
\text { during event }\end{array}$ & $\begin{array}{c}\text { Monthly } \\
\text { mean value }\end{array}$ & \\
\hline 20-24 August & 53 & 3.09 & 0.93 & 0.14 & 36 & 51 & 55 & 35 \\
\hline 26-28 August & 45 & 3.86 & 0.91 & 0.14 & 48 & 53 & 55 & 13 \\
\hline 17-21 September & 56 & 2.76 & 0.34 & 0.13 & 37 & 49 & 56 & 34 \\
\hline 13-14 October & 27 & 3.88 & 1.04 & 0.02 & 32 & 48 & 55 & 42 \\
\hline 25-27 October & 97 & 4.17 & 0.33 & 0.02 & 45 & 51 & 55 & 18 \\
\hline 13-17 November & 31 & 0.28 & 0.08 & 0.02 & 39 & 45 & 57 & 32 \\
\hline $\begin{array}{l}\text { 29-30 November } \\
1-2 \text { December }\end{array}$ & 53 & 0.58 & 0.04 & 0.02 & 35 & 46 & 57 & 39 \\
\hline
\end{tabular}

during the considered period, the hourly mean wind velocity recorded at MTC during the dust transport events $(10.1 \mathrm{~m} / \mathrm{s})$ was more than twice that during "normal" conditions without dust transport. Located at a distance of about $1600 \mathrm{~km}$ from the African deserts, the Saharan air masses can directly reach the measurement site in a few days. As obtained from backtrajectory analysis, during the period of the present study (June-December 2000) the mean air mass travel time from the north African coast to MTC was 64 hours, but in about $50 \%$ of the cases it took less than $53 \mathrm{~h}$. The fastest transports occurred during the 13-14 October and 8-9 December events, when in average African air masses took only $27 \mathrm{~h}$ to reach MTC (Table 1).

During the MINATROC project (Mineral Dust and Tropospheric Chemistry) an intensive measurement campaign took place at MTC during the summer of 2000 (see companion papers in this issue). After the intensive campaign from 1 June to 5 July, measurements of surface ozone and aerosol size distribution were continued till the end of the year. Ozone was measured with an UV-absorption analyser (Dasibi 1108) with an accuracy of better than 5\% and one minute time resolution. The air inlet was placed at $8 \mathrm{~m}$ above the ground. Aerosol concentrations and size distributions of particles with aerodynamic diameters between 0.30 and $20 \mu \mathrm{m}$ were measured with an optical particle counter (OPC) (Particle Size Analyser Grimm Mod. 1.108) in 15 size channels with one minute time resolution. A built-in flow-controlled pump was used to draw in the air sample through the sampling head. These measurements permitted us to distinguish between coarse $\left(1 \mu \mathrm{m}<D_{p}<20 \mu \mathrm{m}\right)$ and fine $\left(0.3 \mu \mathrm{m}<D_{p} \leq 1 \mu \mathrm{m}\right)$ aerosol particles (see Hanisch and
Crowley, 2003) which - as we shall show below - have a quite different relationship with ozone. This extensive data set of aerosol size distribution constitutes the first continuous dust record with high time resolution (interrupted only from 6 July to 4 August 2000) carried out in the free troposphere in this part of the northern Mediterranean area.

\subsection{Trajectory model description and application to field concentration}

We used the Lagrangian model Flextra (Stohl et al., 1995) to calculate three-dimensional 10-day back-trajectories arriving at MTC every three hours. Flextra uses meteorological analysis fields (every $6 \mathrm{~h}$ ) plus 3-h forecast fields produced by the numerical weather prediction model of the European Centre for Medium Range Weather Forecasts (ECMWF). Position information along the trajectories was available every $3 \mathrm{~h}$. Typical trajectory errors are about $10-20 \%$ of the travel distance (Stohl, 1998), but individual trajectories can have much larger errors depending on the meteorological situation. Further errors in tracing the air masses can be caused by the difference between the real topography and the model topography around MTC, which can be quite large.

To investigate the correlation between air mass origins and the ozone and aerosol (fine and coarse) concentrations recorded at MTC, we applied the trajectory statistics method of Seibert et al. (1994). This simple method has the potential to determine the source regions of measured substances using only the measurement data and the trajectories, without involving a detailed model of the emission, transformation and removal processes occurring in an air mass. Thus, it also 


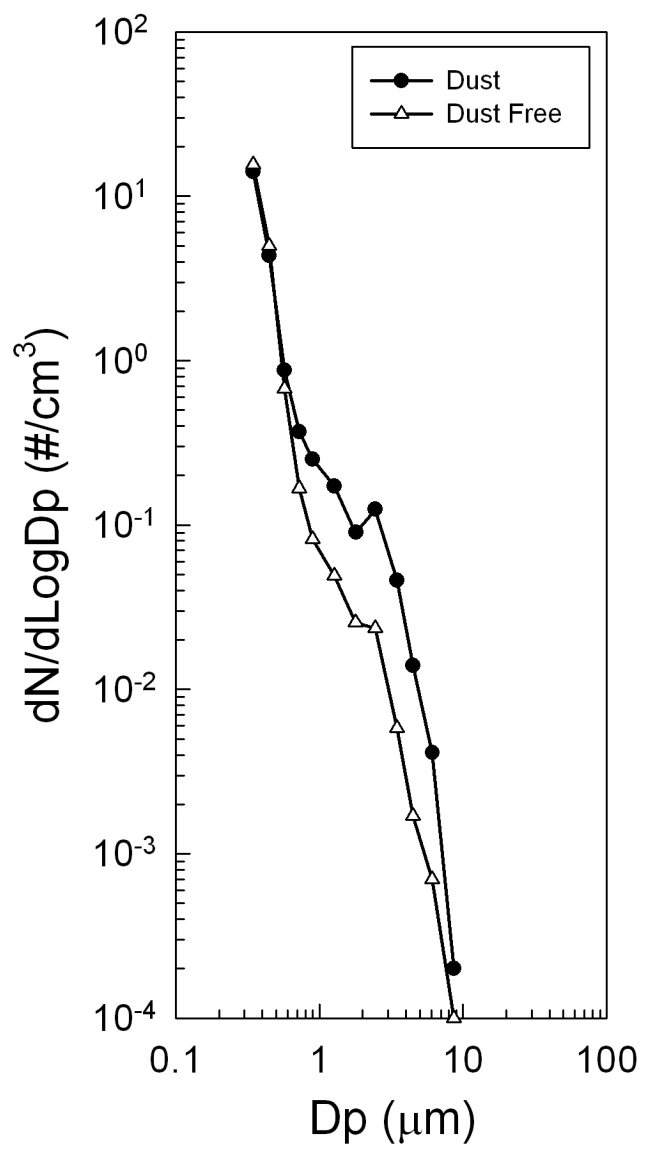

Fig. 1. Average aerosol number size distribution at MTC during Saharan dust events and dust-free conditions.

avoids the errors associated with these complex models and yields a measurement-based and receptor-oriented estimate of the sources of atmospheric trace species. In order to identify the source areas of a specific species (in our case ozone or aerosol concentrations) monitored at the measurement site, a so-called concentration field on a geographical grid (horizontal resolution $1^{\circ} \times 1^{\circ}$ ) is calculated with this method by attributing a measured concentration to every point along the trajectory arriving at the time of measurement. Considering all the trajectories and all the data recorded during the period of study, a mean concentration is obtained for each grid cell of the concentration field.

Assuming $m, n$ to be the indices of the horizontal grid, $l$ the index of each trajectory, $M$ the total number of the applied trajectories, $c_{l}$ the concentration recorded at the arrival of trajectory $l$ and $\tau_{m n l}$ the time spent in the cell $(m, n)$ by the trajectory $l$, the mean concentration was calculated by using the following formula:

$\log \left(\bar{C}_{m n}\right)=\frac{1}{\sum_{l=1}^{M} \tau_{m n l}} \sum_{l=1}^{M} \log \left(c_{l}\right) \tau_{m n l}$
The concentration field obtained in this way can be interpreted as the distribution of sources contributing to the measured values at MTC. In order to eliminate small-scale variations in the concentration field which are not statistically significant, a 9-point smoothing operator was applied for each cell. To avoid that significant features are removed, the smoothing procedure was applied only for those values exceeding an interval calculated on the $95 \%$ confidence level for a $t$-statistic. The statistic was applied to the number of trajectories passing across each cell, assuming that individual measured values were independent from each other.

The concentration field method by Seibert et al. (1994) is known to underestimate the spatial gradients of the source fields, since the concentrations measured at the receptor location are smeared out along the segments of the associated trajectory, while actual emissions may take place only in some segments (Wotawa and Kröger, 1999). However, as we focus on the contributions of a large area (i.e. north Africa) a high spatial resolution of the concentration field is not required in our case. Moreover, the resulting concentration fields have to be interpreted as source fields contributing specifically to the concentration at MTC. The actual spatial distribution of the considered species or its sources may be different because the meteorological conditions (and thus also the emission, transformation and removal processes) are specific for the pathway towards MTC (Stohl, 1998). Furthermore, the density of the trajectory information and thus the reliability of the method decreases with distance from MTC. For another receptor site the source field may therefore look slightly different.

\subsection{TOMS aerosol index}

The absorbing aerosol index (AI) from the Total Ozone Mapping Spectrometer (TOMS), defined as the difference between the backscattered radiation measured in two ultraviolet channels, provides a linear relationship with the aerosol optical depth for smoke and dust: the larger the aerosol index, the higher the optical depth. Although negative AI values are usually related to non-absorbing particulate matter for which aerosol scattering dominates over absorption (Torres et al., 1998), small negative values (i.e. AI $>-2$ ) could also be indicative for a weakly absorbing particle layer not far from the Earth's surface. The AI archive by TOMS constitutes an easy-to-use satellite data set available for the entire globe. Maps of the aerosol index are available with a resolution of $1.25^{\circ}$ in longitude by $1^{\circ}$ in latitude. The "Earth Probe" satellite, which hosts the TOMS spectrometer, has a polar orbit with a local passing time around 11:00 a.m. over MTC, with a shift of about $30 \mathrm{~min}$ varying from year to year. Although the absorbing AI has severe drawbacks in terms of quantitative validation of the dust emissions, recent studies suggest that useful information can nevertheless be retrieved with a reasonable accuracy (Chiapello and Moulin, 2002; Torres et al., 2002). In fact, in order to highlight persistent dust sources 


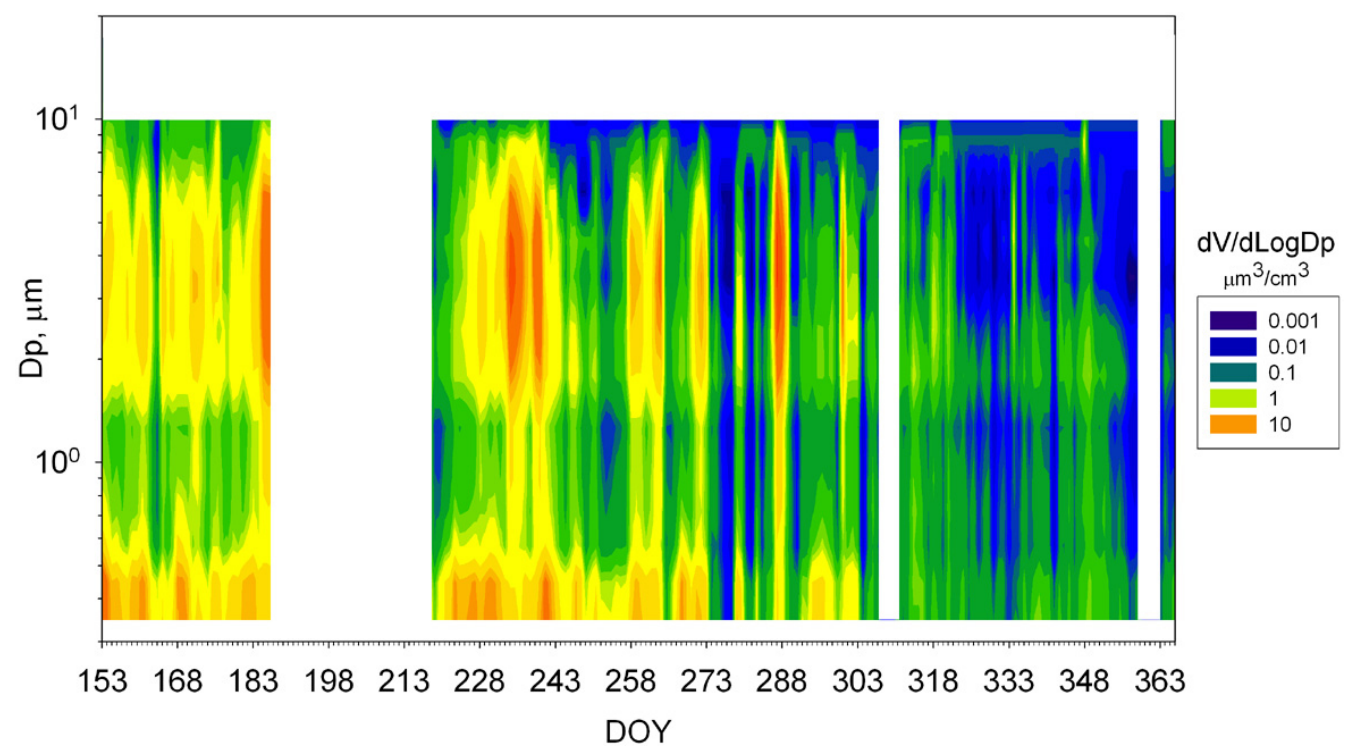

Fig. 2. Time series of the aerosol volume size distribution at MTC during the period June-December 2000.

and typical dust transports in atmosphere, a 13-year climatology (1980-1992) of TOMS-AI was systematically examined by Prospero et al. (2002).

\subsection{Identification of Saharan dust reaching Mt. Cimone}

The identification of Saharan dust episodes was conducted by analysing the hourly number concentration of coarse aerosol particles, considered as a marker of mineral dust present at Mt. Cimone (Van Dingenen et al., 2001). Applying the lowpass filter of Kolmogrov-Zurbenko (Zurbenko, 1986), the strong dust transport events characterised by coarse particle peaks higher than the monthly 75 percentile were identified. In order to deduce the origin of coarse peak events, back-trajectories from MTC were calculated. In particular, the strong dust episodes characterized by at least 3 trajectories/day originated from the north Africa geographical box $\left(10^{\circ} \mathrm{N}-35^{\circ} \mathrm{N} ; 15^{\circ} \mathrm{W}-30^{\circ} \mathrm{E}\right)$, have been considered as "Saharan dust events". This guarantees the undoubted origin of north African air masses. This methodology allowed us to select 12 Saharan dust events at MTC in the period JuneDecember 2000, as summarised in Table 1. In order to corroborate the dust events, additional information was obtained from satellite images from SeaWiFS - Sea viewing Wide Field-of-view Sensor (McClain et al., 1998), model results of dust optical depth from NAAPS - Navy Aerosol Analysis and Prediction System (Hogan et al., 1991, 1993) and aerosol loading from IcoD/DREAM - Dust Regional Atmospheric Model (Nickovic et al., 2001). The strongest Saharan dust event among the 12 recorded at MTC occurred on 25-27 October 2000, when coarse number concentration of $4.17 \mathrm{~N} \mathrm{~cm}^{-3}$, compared with the monthly mean value of $0.02 \mathrm{~N} \mathrm{~cm}^{-3}$, was measured. The $50 \%$ of dust events was characterised by coarse peak number concentration greater than $2.70 \mathrm{~N} \mathrm{~cm}^{-3}$.

\section{Results and discussion}

\subsection{Analysis of aerosol during dust transport episodes}

\subsubsection{Mt. Cimone}

Saharan dust episodes brought about pronounced changes in the aerosol size distribution and in the chemical composition of aerosols compared to dust free conditions at MTC (Van Dingenen et al., 2001). This is illustrated in Fig. 1, which shows average aerosol number size distributions during Saharan dust events and under dust-free conditions at MTC. The episodic appearance of the coarse (dust) mode aerosol during the period June-December can clearly be seen in the time series of the aerosol volume size distribution in Fig. 2. It can also be seen that dust events occurred most frequently from June to October.

In order to identify the major dust production areas during our period of study, we used the TOMS-AI data. Figure 3 shows a map of the average of all positive AI values for the June-December 2000 period. The areas of maximum mean AI likely correspond to the main source regions for mobilized dust and match well with a five-year TOMS-AI analysis for the Mediterranean region (Israelevich et al., 2002). The Chad basin (about $16^{\circ} \mathrm{N} ; 16^{\circ} \mathrm{E}$ ) and the Eljouf basin in Mali (about $19^{\circ} \mathrm{N} ; 6^{\circ} \mathrm{W}$ ) appeared as the main dust source areas, while minor source areas can be identified in Libya, between Algeria and Tunisia, in the Arabian Peninsula and in Northern Sudan. In spite of the short period of investigation, it 


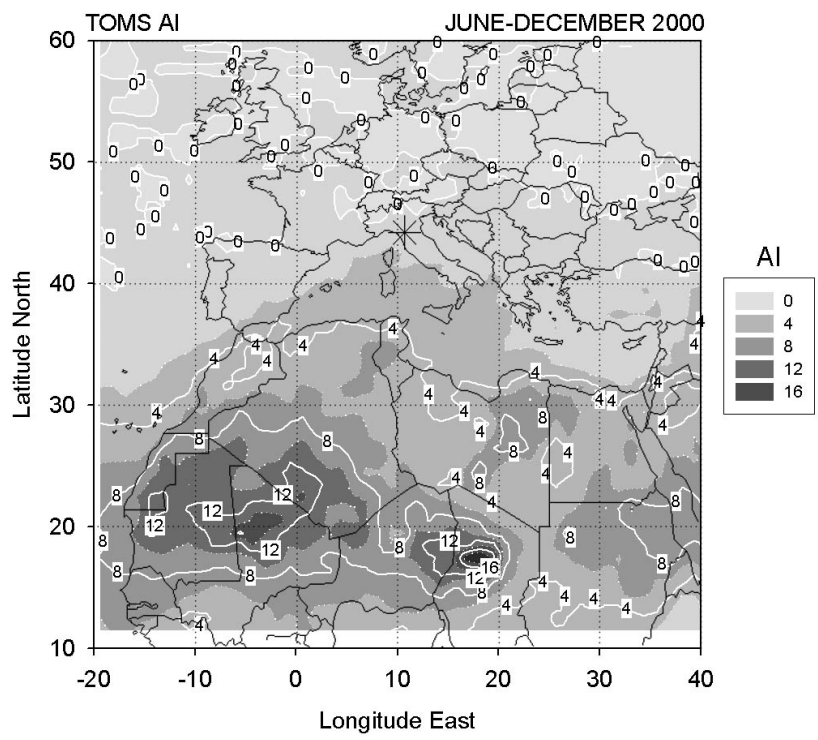

Fig. 3. Average spatial distribution of positive TOMS-AI over north Africa and Europe for the period June-December 2000.

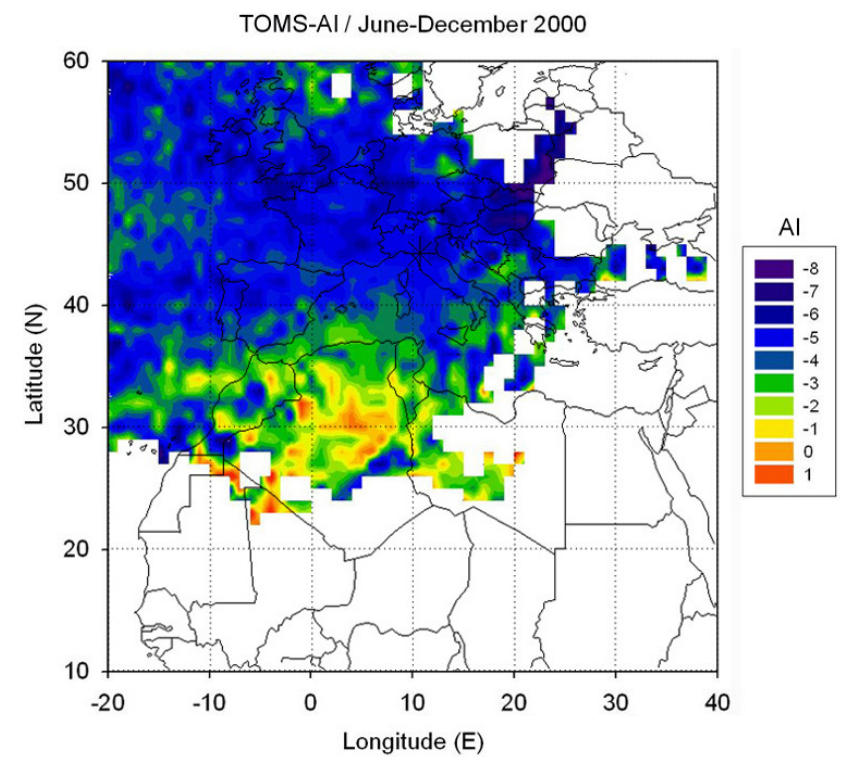

Fig. 4. Concentration field for TOMS-AI retrieved for the MTC pixel area as obtained by the trajectory statistical analysis, JuneDecember 2000.

is evident that enhanced positive AI values extend into the Mediterranean region, indicating active dust transport.

In order to confirm the transport of aerosol in the troposphere over the MTC area, we retrieved the daily TOMS-AI value for the MTC pixel area (pixel size $1.25^{\circ}$ Lon., $1.00^{\circ}$ Lat.) and combined these data with the back-trajectories ending at MTC. For our purpose we made the assumption that the daily AI values are representative for $24 \mathrm{~h}$, attributing the same measured value to all the eight daily trajectories. We

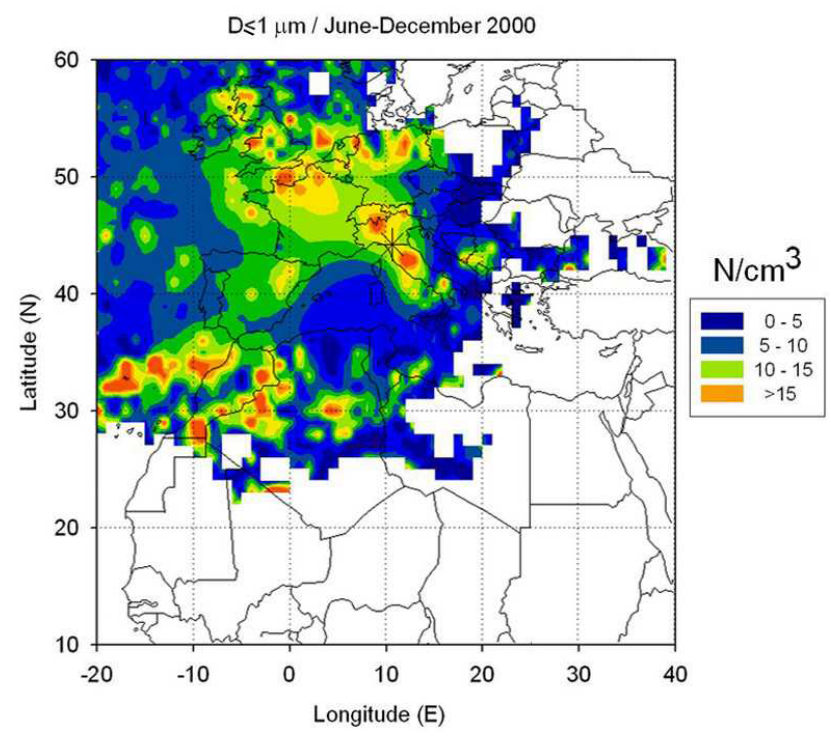

Fig. 5. Number concentration $\left(\mathrm{N} / \mathrm{cm}^{3}\right)$ field for fine aerosol $\left(D_{p} \leq 1 \mu \mathrm{m}\right)$ as obtained by the trajectory statistical analysis, JuneDecember 2000.

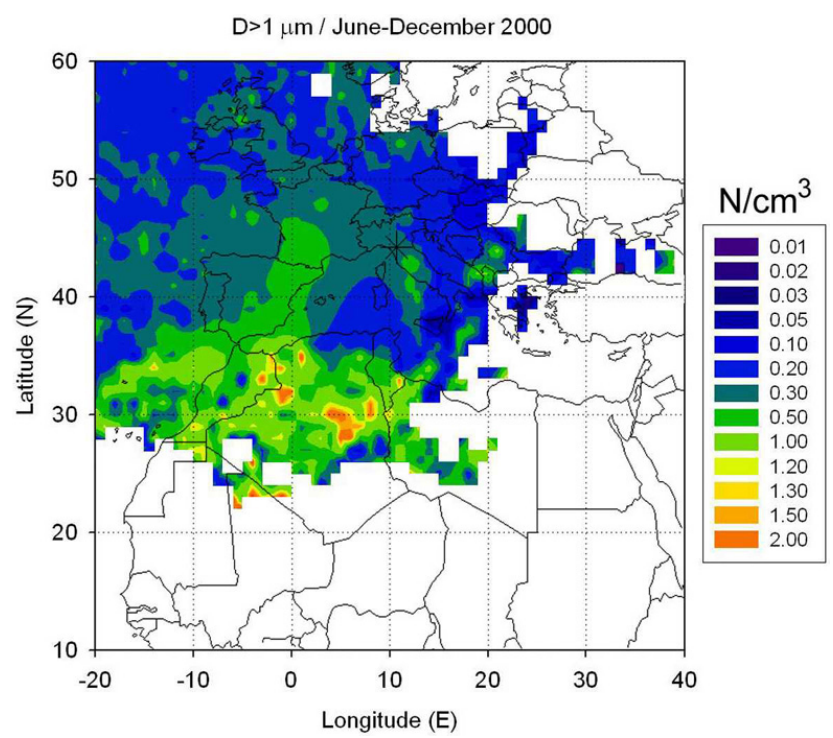

Fig. 6. Number concentration $\left(\mathrm{N} / \mathrm{cm}^{3}\right)$ field for coarse aerosol $\left(D_{p}>1 \mu \mathrm{m}\right)$ as obtained by the trajectory statistical analysis, JuneDecember 2000.

furthermore assumed that usually the trajectories ending at the altitude of MTC are representative for the dust transport. This is not an unlikely assumption, because the dust is frequently transported in layers in the lower free troposphere at about the MTC altitude (Hamonou et al., 1999). In order to identify the dust sources contributing to the dust in the MTC pixel (as indicated by the TOMS-AI), trajectory statistics were applied to the combined data set. The results of this analysis (Fig. 4) clearly show that positive TOMS-AI values 


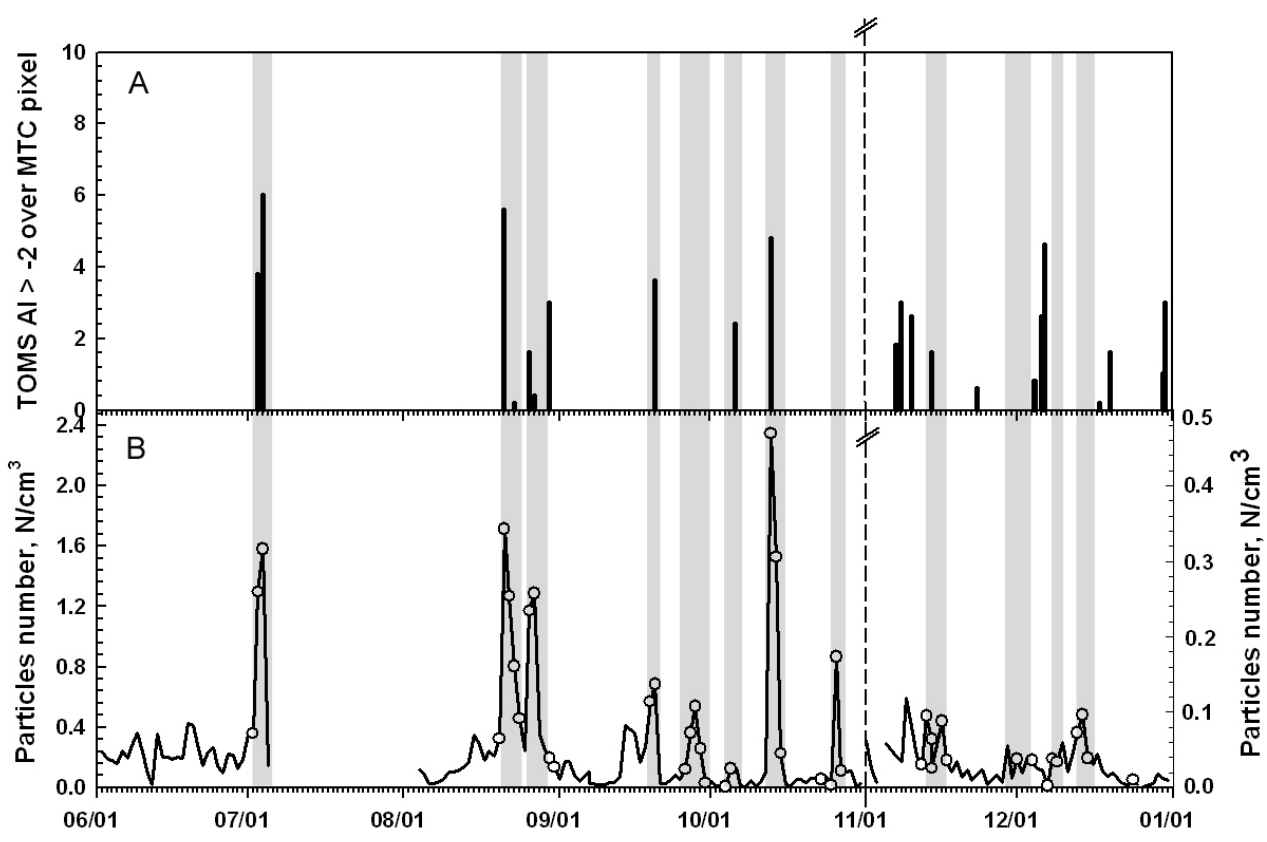

Fig. 7. Daily positive values of TOMS-AI for the MTC pixel area (A) and daily coarse aerosol number concentration recorded at Mt. Cimone (B) during the period June-December 2000 (November-December right scale). White circles represent days during which back-trajectories originated from north Africa. Coloured bars represent the duration of the dust transport events.

at the location of MTC are associated with transport from north Africa, with the principal source region being located in Algeria.

In order to determine the main source regions for the aerosols measured in situ, we applied the trajectory statistics method to both coarse and fine fractions of the particle number concentrations measured at MTC during the period June-December 2000. The number concentration field for the fine particle is shown in Fig. 5. The highest number concentrations of fine particles, which are mostly produced by transformation of gaseous compounds into the liquid or solid phase (Hering et al., 1998; Raes et al., 2000), are mainly related to regions with strong anthropogenic sources of precursor gases like central and Northern Italy, and continental north and North-Eastern Europe. In these areas the contribution of fine particles directly emitted by combustion processes and produced by photochemical reactions is very important, because they take place in an atmosphere rich in ammonium nitrate and ammonium sulphate (Bowman et al., 1995). Enhanced values in the number concentration field are also found over Northern Africa, possibly indicating dust mobilization as a secondary source for fine-mode aerosols. In fact, as evidenced in Fig. 2, Saharan dust events are often associated not only with enhanced concentrations of the coarse-mode aerosols, but also with enhancements in smaller aerosols (Gomes et al., 1990).

Figure 6 shows the number concentration field for the coarse fraction. The highest coarse aerosol number concentrations measured at MTC are usually associated with low latitude air masses originating in north Africa lower troposphere, particularly in Algeria (Fig. 6). These trajectories originated at altitudes below $1500 \mathrm{~m}$, where soil dust is mobilized during dust storms. The concentration field for coarse aerosols number concentration is in good agreement with the similar analysis carried out for the TOMS AI data (Fig. 4) and confirms that north Africa is the principal source region for coarse aerosol measured at MTC. To evaluate the agreement between these two concentration fields we calculated a simple linear correlation coefficient. The close agreement $(\mathrm{r}=0.62)$ between the TOMS AI concentration fields and the coarse particle number concentrations is understandable as a consequence of the strong correlation between the time series of these two parameters (Fig. 7a and b). The maximum of coarse and fine aerosol as well as of TOMS AI concentration field north of the Canary Islands is likely an artefact of the statistical methodology applied. It is possibly caused by dust (fine and coarse mode) mobilized over north Africa and transported along an anticyclonic pathway first northwestward over the Atlantic ocean and then north-eastward over the Mediterranean basin (Rodriguez et al., 2001). This pathway was observed, for instance, during the episodes on 2-4 July, 20-24 August and 26-30 September. As the trajectory statistics method applied here attributes the measured concentration to the entire trajectory and not to the actual location of the emission (Stohl, 1996), a maximum can also occur in a region where several of the back trajectories during the high-concentration events passed through after passing the actual source regions. 

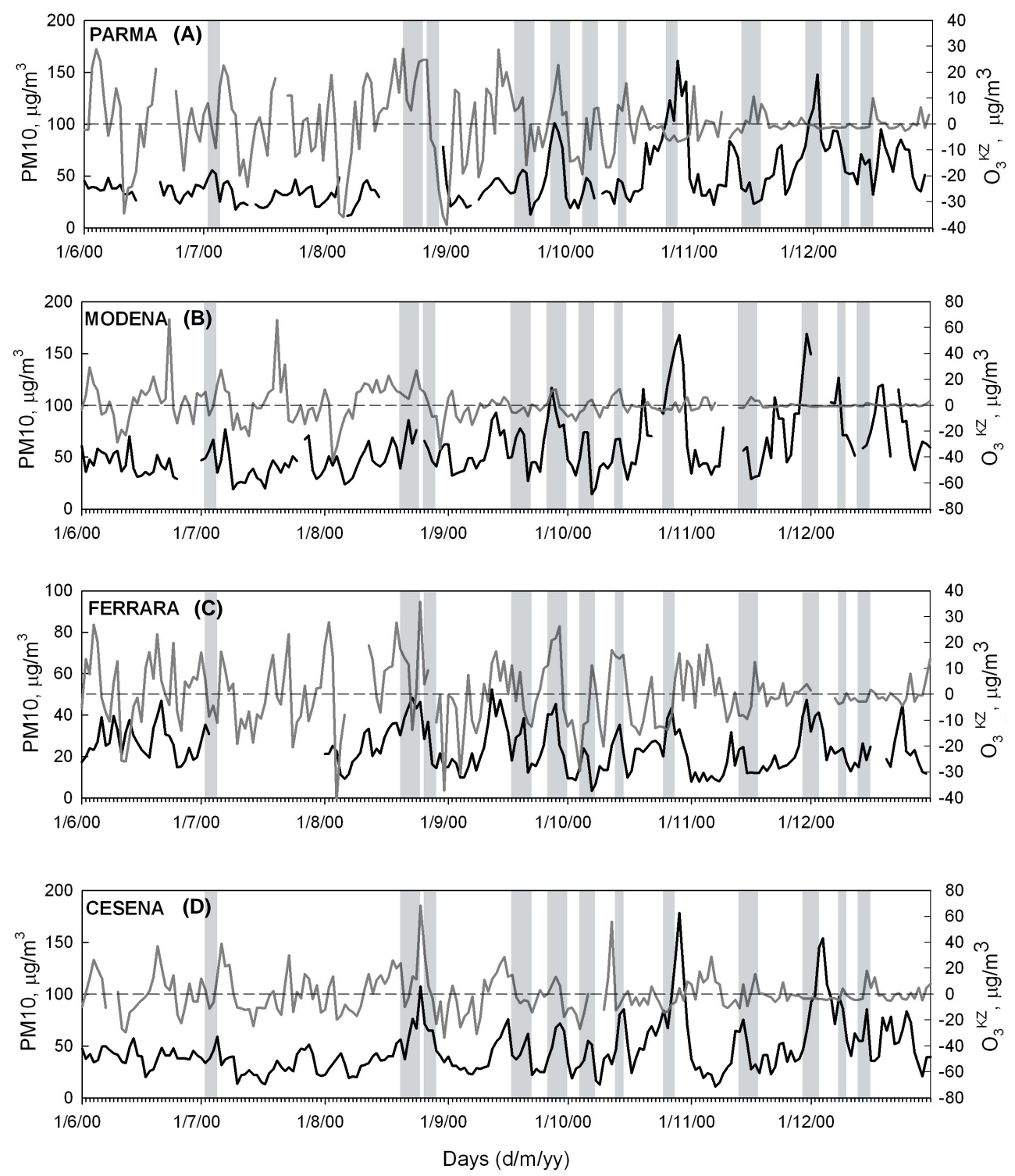

Fig. 8. Time series of $\mathrm{PM}_{10}$ (black line) and $\mathrm{O}_{3}^{\mathrm{KZ}}$ (grey line, see text for definition) concentration measured in the Po valley urban areas: Parma (A), Modena (B), Ferrara (C) and Cesena (D) from June to December 2000. Coloured bars represent the duration of the dust transport events as identified at the MTC station.

\subsubsection{The Po valley}

After Saharan dust plumes have reached MTC, they often move further northward and eastward and eventually reach Northern Italy, the Alps and central Europe and influence the $\mathrm{PM}_{10}$ aerosol concentrations there. In the Po valley, during the period of study, several environmental monitoring stations of the "Agenzia Regionale Prevenzione e Ambiente - Emilia Romagna" (ARPA-ER) detected clear increases in the $\mathrm{PM}_{10}$ concentrations during or shortly after Saharan dust events at MTC. In fact, after reaching MTC, dust clouds take some hours to spread over Po valley, and often also reach the surface. Daily $\mathrm{PM}_{10}$ concentrations recorded at the urban stations of Parma (64 m asl), Modena (56 m asl), Cesena (27 m asl) and the rural station of Ferrara (10 m asl) are shown in Fig. 8. For the greater part of the events, these increases were significant with respect to the average concentrations at the $95 \%$ level according to Student's t-test (Table 2).

The Directive 1999/30/EC of the European Union states that the future (from 2010) daily mean $\mathrm{PM}_{10}$ concentrations must not exceed $50 \mu \mathrm{g} / \mathrm{m}^{3}$ more often than on 7 days per year. During the Saharan dust episodes, 12, 19 and 18 days exceeding the daily PM10 limit were recorded at Parma, Modena and Cesena, while no days exceeding the daily limit were found at the rural station of Ferrara. This analysis 
confirms that the contribution of mineral aerosol on the urban $\mathrm{PM}_{10}$ values can be very critical, favouring threshold exceedances. In order to evaluate the Saharan dust contribution on $\mathrm{PM}_{10}$ in the Po valley area during the dust events identified as significant, for each stations we calculated the average $\mathrm{PM}_{10}$ increase $\left(\Delta \mathrm{PM}_{10}\right)$ in respect with the typical seasonal values calculated by the Kolmogrov-Zurbenko filter (hereinafter KZ). The obtained values, shown as percentage increases in Table 2, suggest that Saharan dust events could modify significantly the $\mathrm{PM}_{10}$ concentrations recorded at urban and rural sites in the Po valley area.

3.2 Ozone analysis and aerosol correlation during dust episodes

\subsubsection{Mt. Cimone}

Because of its high mountain location, no ozone diurnal variations are normally recorded at MTC, except for some periods during the warm season when a small reverse diurnal variation can be caused by the local upslope winds, indicating that the station samples the free troposphere most of the time (Bonasoni et al., 2000). The seasonal ozone concentration ranges from about $40 \mathrm{ppbv}$ in winter to $65 \mathrm{ppbv}$ in summer. A concentration field for $\mathrm{O}_{3}$ source areas has been obtained by applying the trajectory statistics method to the MTC ozone data for the period June-December 2000 (Fig. 9). High ozone values are associated with air masses coming from populated and industrialised areas in north and North-Eastern Europe, low ozone concentrations are associated with air masses coming from the south and southwest. The same analysis (not shown) has been applied for warm (June-September) and cold (October-December) seasons showing similar results, even if in respect to the cold, the warm season is characterised by higher $\mathrm{O}_{3}$ values.

These results are consistent, at least qualitatively, with pictures of European ozone source and production rates obtained by Wotawa et al. (2000) by applying both a statistical trajectory source analysis and a Lagrangian photochemical box model. This agrees with the existence of a northsouth gradient of ozone across the Mediterranean region, as reported by Balkanski et al. (2003). The areas characterised by high ozone concentrations are very similar to those identified as the source areas for fine particles measured at MTC (Fig. 5). Particularly, the areas of North-Western Europe, the Po valley, central and south Italy as well as the Balkan peninsula show the highest levels of both fine particles (Fig. 5) and ozone (Fig. 9), likely due to anthropogenic emissions of the precursors for the formation of both ozone and particles. On the contrary, low ozone concentration values are associated with air masses coming from the Southern Mediterranean and north-Africa regions, which are characterised by relatively small anthropogenic emissions, but strong dust sources (north-Africa and Sahara areas), as shown by the TOMS-AI maps (Fig. 4). It is of interest to look more in detail into

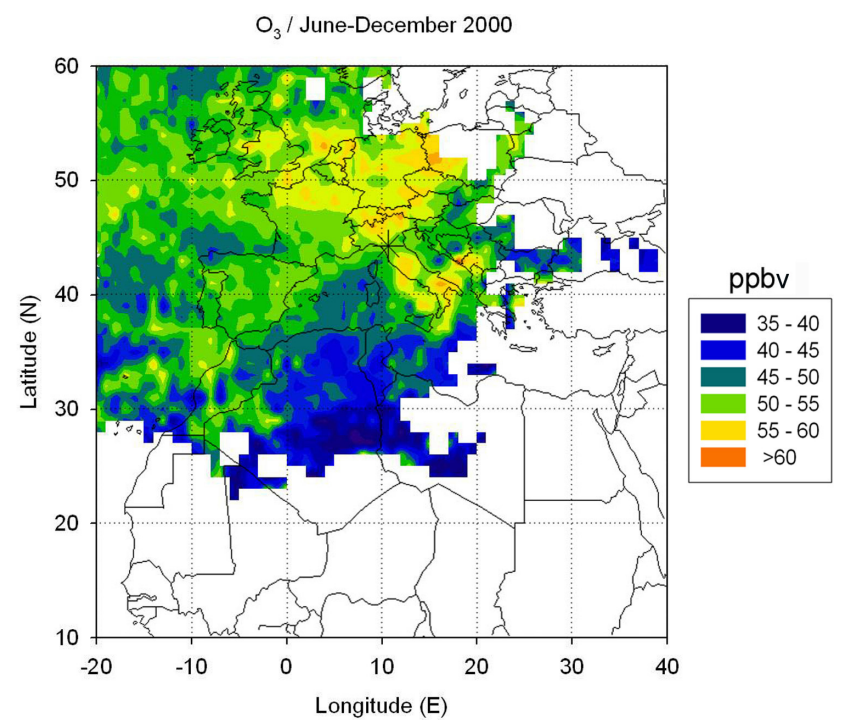

Fig. 9. Concentration field for ozone (ppbv) as obtained by the trajectory statistical analysis, June-December 2000.

the anti-correlation between the spatial distribution of the sources of $\mathrm{O}_{3}$ (Fig. 9) and coarse particles (Fig. 6).

In order to investigate the ozone behaviour during Saharan dust events at MTC and to study the possible influence of coarse aerosols on the ozone concentrations, we analysed the relationship between the hourly data of the de-trended concentrations of ozone and the number concentrations of coarse particles. We de-trended the ozone data in order to remove the strong seasonal variation of ozone. The de-trended ozone is obtained by:

$O_{3}^{D E T}=O_{3}^{M T C} \frac{O_{3}^{\text {period }}}{\overline{O_{3}^{r m}}}$

where $\mathrm{O}_{3}^{D E T}$ is the ozone concentration value corrected for the seasonal variations, $\mathrm{O}_{3}^{M T C}$ is the hourly ozone concentration measured at MTC, $\mathrm{O}_{3}^{\text {period }}$ is the averaged concentration for the period June-December 2000 and $\mathrm{O}_{3}^{r m}$ is a running mean concentration. Since the phenomena on which we focused occur on synoptic time scales (i.e. a few days), a 21 days running mean was used (Vukovich, 1997; Weischet, 1977).

During the 12 dust episodes, the de-trended ozone concentrations (Fig. 10) were on average between 4\% (26-30 September and 8-9 December) and 21\% (13-17 November) lower than the de-trended mean value. The hourly $\mathrm{O}_{3}$ minima during the strongest dust events (13-14 October) were even about $42 \%$ below the mean value (Table 1). Ozone minima were measured simultaneously with peaks of coarse aerosol values so that an anticorrelation between coarse particle and ozone concentrations could be supposed (Fig. 10). During the few cases when a high number concentration of coarse particles was not due to Saharan air mass transports 
Table 2. Mean $\pm 95 \%$ confidence interval for $\mathrm{PM}_{10}$ and $\mathrm{O}_{3}$ measurements in warm (June-September) and cold (October-December) season at the ARPA-ER environmental monitoring stations in the Po valley area. Number of significant dust events (see text) for $\mathrm{PM}_{10}$ and $\mathrm{O}_{3}$ among those recorded at MTC, together with the average increase and decrease $\Delta \mathrm{PM}_{10}$ and $\Delta \mathrm{O}_{3}$ from their seasonal values are also reported.

\begin{tabular}{lcccc|crccc}
\hline \multirow{3}{*}{ Station } & \multicolumn{4}{c}{$\mathrm{PM}_{10}\left(\mu \mathrm{g} / \mathrm{m}^{3}\right)$} & \multicolumn{4}{c}{$\mathrm{O}_{3}\left(\mu \mathrm{g} / \mathrm{m}^{3}\right)$} \\
\cline { 2 - 9 } & Warm & Cold & $\begin{array}{c}\text { Significant } \\
\text { events }\end{array}$ & $\Delta \mathrm{PM}_{10}$ & Warm & Cold & $\begin{array}{c}\text { Significant } \\
\text { events }\end{array}$ & $\Delta \mathrm{O}_{3}$ \\
\hline Parma & $36 \pm 3$ & $59 \pm 6$ & 8 & $36.7 \%$ & $71 \pm 3$ & $10 \pm 1$ & 7 & $-6.2 \%$ \\
Modena & $50 \pm 3$ & $71 \pm 7$ & 8 & $33.5 \%$ & $51 \pm 4$ & $5 \pm 1$ & 7 & $-4.8 \%$ \\
Cesena & $39 \pm 3$ & $55 \pm 6$ & 11 & $21.9 \%$ & $71 \pm 4$ & $15 \pm 2$ & 11 & $-2.7 \%$ \\
Ferrara & $27 \pm 2$ & $21 \pm 2$ & 12 & $19.2 \%$ & $61 \pm 3$ & $16 \pm 2$ & 8 & $-12.8 \%$ \\
\hline
\end{tabular}

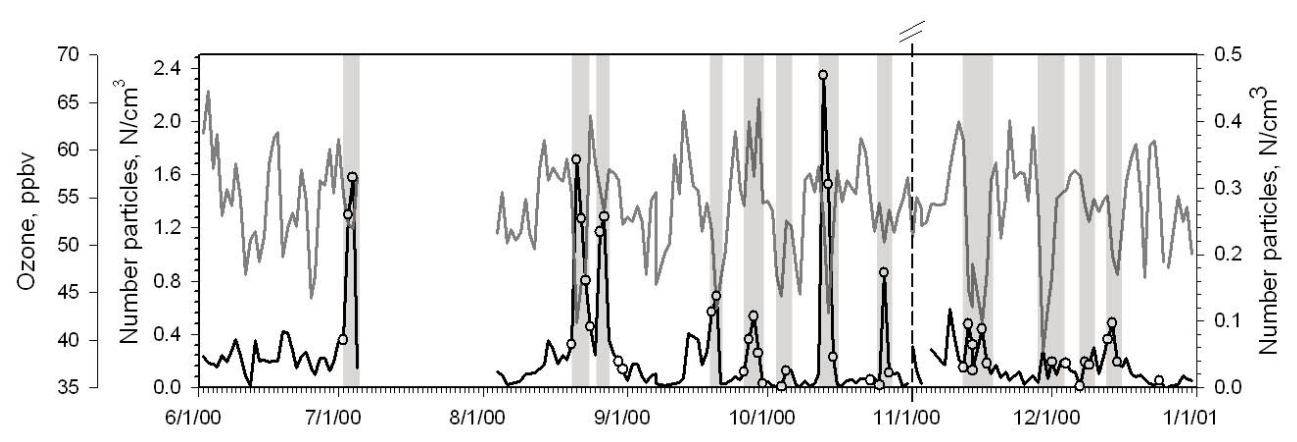

Fig. 10. Daily coarse aerosol concentration (black line) and daily de-trended ozone (grey line) recorded at MTC during the period JuneDecember 2000 (for coarse aerosol: November-December right scale). White circles represent days during which back-trajectories originated from north Africa. Coloured bars indicate the periods of the dust transport events. See text for the definition of the de-trended ozone concentration.

(e.g. an episode on 10 November when the air came from the Gulf of Genoa), an ozone increase was recorded.

The relationship between the values of the de-trended ozone concentration with the fine and coarse aerosol volume has been analysed using a box-and-whiskers plot. The boxes and whiskers denote the 10, 25, 50, 75 and 90 percentiles, and the bold lines the mean values of the ozone distributions for different classes of the fine- and coarse-mode particle volume concentrations (Fig. 11). The whole distribution of the de-trended ozone concentrations shifts towards higher values with increasing aerosol volume concentrations of the fine-mode particles. Particularly the highest $\mathrm{O}_{3}$ values, which occur in polluted air masses, are associated to high fine aerosol volume concentrations ranging between 2 and $10 \mu \mathrm{m}^{3} / \mathrm{cm}^{3}$. In contrast, Fig. 11 shows the lowest ozone values for high values of the coarse-mode aerosol volume concentrations which are typical for the intrusions of Saharan dust, with the lowest ozone values recorded for coarse-mode aerosol volumes $\geq 5-10 \mu \mathrm{m}^{3} / \mathrm{cm}^{3}$. In fact, the high aerosol volume classes $\left(>2-5 \mu \mathrm{m}^{3} / \mathrm{cm}^{3}\right)$ occurred only during the Saharan dust events.

To further explore the relation between ozone concentrations and dust loading, three cases were distinguished, based on coarse-mode particle volume concentrations and the source region of back trajectories: (a) north African origin during "Saharan dust events", (b) north African origin outside "Saharan dust events", (c) all the other data. In order to select air masses coming from north Africa, we considered back-trajectories originating from the geographical box defined in the paragraph 2.4 and roughly coincident with the major dust production areas as shown in Fig. 3. Thus, for classes (a) and (b) we analysed mean de-trended ozone values calculated for a 3-h period centred around the time of back-trajectory arrival at MTC. During the period of our study $16 \%$ of the calculated back-trajectories were characterized by a north African origin, and only $26 \%$ of these were not accompanied by strong dust transport. On average the trajectories coming from North Africa are characterised by travel altitudes of $2000-2500 \mathrm{~m}$ asl. Table 3 shows the mean de-trended ozone concentrations for the three classes and different months. Correlation between de-trended ozone data and air mass characteristics was investigated using oneway ANOVA analysis (Formenti et al., 2001). This test compares means of 3 or more samples to estimate if the means can be considered significantly different. Due to the few cases available for condition (b) in September and November, the ozone-averaged values were not calculated for this case and ANOVA not applied. Instead, a Student's 
Table 3. One-way ANOVA analysis of variance for de-trended ozone concentrations in air masses from north Africa during "Saharan dust events" (Dust, class a), from north Africa outside "Saharan dust events" (north Africa, class b) and for other origins and conditions (Other, class c). For each class the arithmetic mean (first row), the variance (second row) and the total number of data (third row) are reported. If the differences are significant the level of significance is also reported. The asterisks denote Student's t-test analysis performed when not enough data are available for north Africa (class b).

\begin{tabular}{|c|c|c|c|c|c|c|c|}
\hline \multicolumn{8}{|c|}{ De-trended ozone concentration (ppbv) } \\
\hline & June-July & August & September & October & November & December & All-period \\
\hline \multirow{3}{*}{ (a) Dust } & 50.0 & 52.0 & 53.2 & 49.0 & 46.0 & 52.1 & 49.8 \\
\hline & 13.3 & 103.3 & 75.5 & 51.6 & 30.0 & 17.9 & 57.2 \\
\hline & 12 & 39 & 30 & 45 & 32 & 14 & 172 \\
\hline \multirow{3}{*}{ (b) north Africa } & 53.4 & 55.4 & & 55.4 & & 52.6 & 54.2 \\
\hline & 85.9 & 70.2 & & 10.5 & & 26.1 & 38.9 \\
\hline & 17 & 12 & & 28 & & 28 & 85 \\
\hline \multirow{3}{*}{ (c) Other } & 55.2 & 54.8 & 54.7 & 54.2 & 54.9 & 54.6 & 54.8 \\
\hline & 45.8 & 27.1 & 43.0 & 28.7 & 44.9 & 25.8 & 36.7 \\
\hline & 247 & 165 & 204 & 176 & 200 & 191 & 1183 \\
\hline Significance & 0.04 & 0.04 & NOT $(*)$ & $10^{-8}$ & $10^{-11}(*)$ & 0.04 & $10^{-19}$ \\
\hline
\end{tabular}

t-test was performed to compare the actual difference between the two means and investigate their significance. The results showed that in all months, except September, the $\mathrm{O}_{3}$ level for class (a) is significantly lower than for classes (b) and (c) which have comparable de-trended $\mathrm{O}_{3}$ concentrations (Table 3). Although there is a large variability in the ozone data during "Saharan dust events" (see Fig. 11), this analysis confirms that ozone concentrations during dust events are systematically reduced. In fact, air masses coming from the north Africa region during dust events are characterised by high values of aerosol mean volumes (greater than about $6.15 \mu \mathrm{m}^{3} / \mathrm{cm}^{3}$ ) and low de-trended ozone concentrations $(50 \pm 8 \mathrm{ppbv}$; mean $\pm 1 \sigma)$ compared to mean values of $0.92 \mu \mathrm{m}^{3} / \mathrm{cm}^{3}$ and $54 \pm 6 \mathrm{ppbv}$ for African air masses outside "Saharan dust events" and $0.63 \mu \mathrm{m}^{3} / \mathrm{cm}^{3}$ and $55 \pm 6 \mathrm{ppbv}$ for all other data. As reported in Table 3, these differences are significant for the one-way ANOVA analysis.

\subsubsection{The Po valley}

As suggested in previous studies (Bian and Zender, 2003; Zhang et al., 1993; Bauer et al., 2004), dust-chemistry interactions could play an important role to explain $\mathrm{O}_{3}$ loss phenomena also inside the planetary boundary layer (PBL). However, due to the many factors influencing the chemical of $\mathrm{O}_{3}$ in a polluted PBL, it is not trivial to investigate possible influences of mineral aerosol on $\mathrm{O}_{3}$ concentrations in urban and rural areas. We analysed daily $\mathrm{O}_{3}$ time series recorded in the Po valley during Saharan dust events identified at MTC. As the Po valley region is characterized by frequent episodes of high air pollution, the solar radiation causes a strong seasonality in the $\mathrm{O}_{3}$ concentrations, with

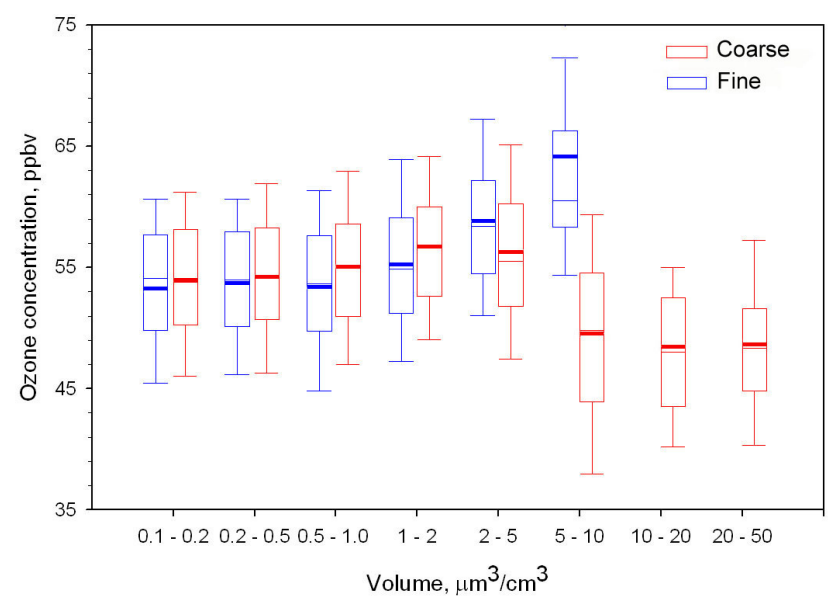

Fig. 11. Box-and-whiskers plot of de-trended ozone versus coarse and fine aerosol volume at MTC for the period from June to December 2000. The box and whiskers denote the 10, 25, 50, 75, and 90 percentiles and the bold lines the mean values of the ozone distributions. The statistics are based on the hourly mean values. The $\mathrm{x}$-axis denotes the aerosol volume classes. Low ozone concentrations for high values of coarse volume are evident.

a maximum in warm and a minimum in cold months (Table 2). In order to analyse small fluctuations we applied the KZ filter: the result for the $\mathrm{O}_{3}$ recorded at the Po valley monitoring stations are presented in Fig. 8 as $\mathrm{O}_{3}^{\mathrm{KZ}}$. In particular, negative $\mathrm{O}_{3}^{\mathrm{KZ}}$ mean that daily $\mathrm{O}_{3}$ concentrations are below their typical seasonal value. Even though less pronounced than at MTC, the influence of Saharan dust events on ozone concentrations can also be seen at the four lowland stations. 
In fact, a statistical analysis showed that during the greater number of dust events, significant (at the 95\% level according to Student's t-test) negative $\mathrm{O}_{3}^{\mathrm{KZ}}$ were recorded (Table 2). By using the same methodology applied to calculate $\Delta \mathrm{PM}_{10}$ (Sect. 3.1.2), we evaluated the $\mathrm{O}_{3}$ reduction $\left(\Delta \mathrm{O}_{3}\right)$ in the Po valley area during Saharan dust events to be significant. For each station, the obtained values are shown in Table 2 as percentage decreases. These preliminary results suggest that air masses rich in Saharan dust could modify not only $\mathrm{O}_{3}$ concentrations in a baseline area (Mt. Cimone), but also in urban and rural sites in the Po valley.

\subsection{Discussion}

The analysis performed at MTC presented a clear statistical relationship between high dust loadings and low ozone concentrations. A similar relationship was also found for urban and rural sites in the Po valley. It is likely that this statistical relationship is due to the change of the photolysis rates in dust plumes and the heterogeneous destruction of ozone on mineral dust, two mechanisms that several authors (Schmitt et al., 1998; Zhang et al., 1994; Dentener et al., 1996; Martin et al., 2002; Bian and Zender, 2003) have suggested to be important. From our data, the relative role of these processes cannot be determined and it cannot be ruled out entirely that this relationship is caused by differences in the source regions of the air masses and associated differences in their chemical composition. Perhaps the dust-loaden air masses already carried lower ozone concentrations before they received the dust injections. However, as the air masses arriving from the same north African source regions without strong dust loading had higher ozone concentrations than the dust-loaden ones, this is an unlikely scenario. Furthermore, Saharan air masses usually travel at altitudes above about 800-700 mb (Sancho et al, 1992; Hamonou et al., 1999) and are very dry (Charlson and Prospero, 1972), as also seen in vertical profiles of humidity, temperature and ozone carried out at the S. Pietro Capofiume WMO station, which is located in the Po valley and close to MTC (Bonasoni et al., 1998). Therefore, ozone destruction by homogeneous chemical reactions is very slow in these air masses. Thus, our analysis can provide independent confirmation of the hypothesis put forward in other studies (Hanisch and Crowley, 2003; Bauer et al., 2004) that significant heterogeneous ozone destruction can occur on the surfaces of the dust aerosols and that desert aerosols can cause a decrease in photolysis rate throughout the troposphere, having a negative impact on ozone concentration in the lower troposphere (He and Carmichel, 1999; Balis et al., 2000; Dentener et al., 1996).

\section{Conclusions}

In this paper we have investigated the relationship between tropospheric ozone and mineral aerosol in the free troposphere of the Northern Mediterranean basin during an experimental campaign performed at the Mt. Cimone baseline station in the period June-December 2000. Saharan dust transport episodes, occurring during this period, were identified using three-dimensional backward trajectories, TOMS aerosol index analysis, aerosol size and mass distribution concentrations. A statistical analysis of the back trajectories combined with the ozone, coarse and fine aerosol measurements as well as the TOMS aerosol index at the location of MTC was done. The result of the trajectory statistics are so-called concentration fields of the respective parameters, which indicate their source regions.

The ozone concentration field showed a positive gradient from north Africa to Europe, mainly due to the large differences between the anthropogenic emissions of ozone precursors, which characterise the two continental regions. In fact, the industrialised regions in north-central Europe and north-central Italy appear as the main source regions for both fine particles and surface ozone. Indeed, a significant positive correlation between surface ozone and fine aerosol concentrations has been found. On the contrary, the Saharan desert is the main source region for coarse particles, clearly suggesting desert dust as the main contributor to coarsemode aerosols. Furthermore, we found a strong anticorrelation between the concentrations of coarse particles and ozone. When southerly winds transported dust clouds from north Africa to MTC, the concentrations of surface ozone at MTC showed a marked decrease compared to normal freetropospheric conditions. On the other hand, there was only a slight reduction in the $\mathrm{O}_{3}$ concentrations when air masses arriving from the south carried no dust. This suggests that high concentrations of coarse mineral aerosol in the atmosphere may lead to significant heterogeneous ozone destruction on the particle surface, thereby affecting the ozone concentrations even in areas very far away from the dust mobilization regions. Nevertheless, it cannot be excluded that absorption by aerosol played a role in reducing photochemistry, thus producing a negative impact on ozone concentrations in the lower troposphere.

Finally, the $\mathrm{PM}_{10}$ and ozone measurements carried out in urban and rural areas of the Po valley during the period of our study, showed that a not negligible influence of Saharan dust transport could be present even in a polluted region of Southern Europe. In fact, high $\mathrm{PM}_{10}$ concentrations in the Po valley were recorded during the Saharan dust events identified at MTC, leading to several exceedances of the future EU air quality limits. Moreover, influence of Saharan dust on daily $\mathrm{O}_{3}$ concentrations in urban and rural areas is possible. However, because of many uncertainties connected with these analyses, this should be considered as an exploratory study that needs further improvement. In particular, chemical 
analysis composition of aerosol in urban and rural areas appears as a necessary step to identify unambiguously the presence of mineral dust at the measurement sites.

Acknowledgements. This work was supported by the European Commission (DG XII) within the framework of the MINATROC (EVK2-1999-00003) and STACCATO (EVK2-1999-00316) projects. We thank the "Ufficio Generale per la Meteorologia" of the Italian Air Force and P. Giambi, C. Magera, D. and P. Amidei, F. Nizzi for their support in the Mt. Cimone MINATROC field campaign. TOMS data were provided by NASA/Goddard Space Flight Center from their Web site. Images of SeaWiFS-NASA satellite as well as DREAM (Euro-Mediterranean Centre on Insular Coastal Dynamics - IcoD) and NAAPS (Naval Research Laboratory - NRL) analysis were provided by the Naval Research Laboratory (Monterey) from their Web site.

Edited by: H. Wernli

\section{References}

Andreae, M. O.: Climate effects of changing atmospheric aerosol levels, in World Survey of Climatology, Future Climate of the World, Vol. 16, edited by Henderson-Sellers, A., 341-392, Elsevier, Amsterdam, 1995.

Ansmann, A., Bösenberg, J., Chaikovsky, A., Comerón, A., Eckhardt, S., Eixmann, R., Freudenthaler, V., Ginoux, P., Komguem, L., Linné, H., Márquez, M. Á. L., Matthias, V., Mattis, I., Mitev, V., Müller, D., Music, S., Nickovic, S., Pelon, J., Sauvage, L., Sobolewsky, P., Srivastava, M. K., Stohl, A., Torres, O., Vaughan, G., Wandinger, U., and Wiegner, M.: Long-range transport of Saharan dust to northern Europe: The 11-16 October 2001 outbreak observed with EARLINET, J. Geophys. Res., 108, 4782, doi:10.1029/2003JD003757, 2003.

Arimoto, R.: Eolian dust and climate: relationships to sources, tropospheric chemistry, transport and deposition, Earth-Sci. Rev., 54, 29-42, 2001.

Balkanski, Y., Bauer, S. E., van Dingenen, R., Bonasoni, P., Schulz, M., Fischer, H., Gobbi, G. P., Hanke, M., Hauglustaine, D., Putaud, J. P., Stohl, A., and Raes, F.: The Mt Cimone, Italy, free tropospheric campaign: principal characteristics of the gaseous and aerosol composition from European pollution, Mediterranean influences and during African dust events, Atmos. Chem. Phys. Discuss., 3, 1753-1776, 2003.

Balis, D. S., Zerefos, C. S., Kourtidis, K., Bais, F., Hofzumahaus, A., Kraus, R., Schmitt, M., and Gobbi, G. P.: Measurements and modeling of photolysis rates during the Photochemical Activity and Ultraviolet Radiation (PAUR) II campaign, J. Geophys. Res., 107, D18, 8138, doi:10.1029/2000DJ000136, 2002.

Bauer, S. E., Balkanski, Y., Schulz, M., Hauglustaine, D. A., and Dentener, F.: Global modeling of heterogeneous chemistry on mineral aerosol surfaces: Influence on tropospheric ozone chemistry and comparison to observations, J. Geophys. Res., 109, D02304, doi:10.1029/2003JD003868, 2004.

Bian, H. and Zender, C. S.: Mineral dust and global tropospheric chemistry: Relative role of photolysis and heterogeneous uptake, J. Geophys. Res., 108, D21, 4672, doi: 10.1029/2002JD003143, 2003.
Bonasoni, P., Colombo, T., Lenaz, R., Giovanelli, G., Evangelisti, F., Ravegnani, F., Santaguida, R., and Tesi, G.: Effect of saharan dust transport on ozone and carbon dioxide concentration, The impact of african dust across the Mediterranean, Environmental Science and Technology Library, Vol. 11, edited by Guerzoni, S. and Chester, R., 313-322, Kluwer Academic Publishers, The Netherlands, 1996.

Bonasoni, P., Bonafè, U., Colombo, T., Santaguida, R., Lenaz, R., and Tesi, G.: Effects of Saharan dust transport on trace gases concentration, in Proceedings of XVIII Quadrennial Ozone Symposium-96, edited by Bojkov, R. D. and Visconti, G., 323326, l'Aquila, Italy, 1998.

Bonasoni, P., Stohl, A., Cristofanelli, P., Calzolari, F., Colombo, T., and Evangelisti, F.: Background ozone variations at Mt. Cimone Station, Atmos. Environ., 34, 5183-5189, 2000.

Bowman, F. M., Pilinis, C., and Seinfeld, J. H.: Ozone and aerosol productivity of reactive organics, Atmos. Environ., 29, 579-589, 1995.

Charlson, T. N. and Prospero, J. M.: The Large Scale movement of Sahara air outbreaks over the Northern equatorial Atlantic, J. Appl. Meteorol, 11, 283-297, 1972.

Chiapello, I. and Moulin C.: TOMS and METEOSAT satellite records of the variability of Saharan dust transport over the Atlantic during the last two decades (1979-1997), Geophys. Res. Lett., 29, 1176, doi:10.1029/2001GL013767, 2002.

D'Almeida, G. A.: A model for Saharan dust transport, J. Clim. Appl. Meteor., 25, 903-916, 1986.

Dentener, F. J. and Crutzen, P.: Reaction of $\mathrm{N}_{2} \mathrm{O}_{5}$ on tropospheric aerosol: Impact on the global distributions of $\mathrm{NO}_{\mathrm{x}}, \mathrm{O}_{3}$ and $\mathrm{OH}$, J. Geophys. Res., 98, 7149-7163, 1993.

Dentener, F. J., Carmichael, G. R., Zhang, Y., Lelieveld, J., and Crutzen, P. J.: The role of mineral aerosols as a reactive surface in the global troposphere, J. Geophys. Res., 101, 22 869-22 889, 1996.

Dickerson, R. R., Kondragunta, S., Stenchikov, G., Civerolo, K. L., Doddrige, B. G., and Holben, B. N.: The impact of aerosols on solar ultraviolet radiation and photochemical smog, Science, 278, 827-830, 1997.

Fabian, P. and Pruchniewicz, P. G.: Meridional distribution of ozone in the troposphere and its seasonal variations, J. Geophys. Res., 82, 2063-2073, 1977.

Fischer, H., Kormann, R., Klüpfel, T., Gurk, C., Königstedt, R., Parchatka, U., Mühle, J., Rhee, T. S., Brenninkmeijer, C. A. M., Bonasoni, P., and Stohl, A.: Ozone production and trace gas correlations during the June 2000 MINATROC intensive measurement campaign at Mt. Cimone, Atmos. Chem. Phys., 3, 725-738, 2003.

Franzen, L. G., Hjelmroos, M., Kaalberg, P., Brostroem-Lunden, E., Juntto, S., and Savolainen, A. L.: The "Yellow snow" episode of northern Fennoscandia, March 1991 - A case study of long distance transport of soil, pollen and stable organic compounds, Atmos. Environ., 28, 3587-3604, 1994.

Formenti, P., Andreae, M. O., Andreae, T. W., Galani, E., Vasaras, A., Zerefos, C., Amiridis, V., Orlovsky, L., Karnieli, A., Wendisch, M., Wex, H., Holben, B. N., Maenhaut, W., and Lelieveld, J.: Aerosol optical proprieties and large-scale transport of air masses: Observation at a coastal and a semiarid site in the eastern Mediterranean during summer 1998, J. Geophys. Res., 106, D9, 9807-9826, 2001. 
Ganor, E.: The frequency of Saharan dust episodes over Tel Aviv, Israel, Atmos. Environ., 28, 2867-2871, 1994.

Gomes, L., Bergametti, G., Coudé-Gaussen, G., and Rognon, P.: Submicron Desert Dusts: A Sandblasting Process, J. Geophys. Res., 95, 13 927-13 935, 1990.

Güsten, H., Heinrich, G., Mönnich, E., Sprung, D., Weppner, J., Ramadan, A. B., Ezz El-Din, M. R. M., Ahmed, D. M., and Hassan, G. K. Y.: On-line measurements of ozone surface fluxes: Part II; Surface-level ozone fluxes onto the Sahara desert, Atmos. Environ., 30, 911-918, 1996.

Hamonou, E., Chazette, P., Balis, D., Dulac, F., Schneider, X., Galani, E., Ancellet, G., and Papayannis, A.: Characterization of the vertical structure of Saharan dust export to the Mediterranean basin, J. Geophys. Res., 104, 22 257-22 270, 1999.

Hanisch, K. and Crowley, J. N.: Ozone decomposition on Saharan dust: an experimental investigation, Atmos. Chem. Phys., 3, 119-130, 2003.

He, S. and Carmichel, G. R.: Sensitivity of photolysis rates and ozone production in the troposphere to aerosol properties, J. Geophys. Res., 104, D21, 26307-26 324, 1999.

Hering, A. M., Staehelin, J., Baltensberger, U., Prevot, A. S. H., Kok, G. L., Schillawski, R. D., and Waldvogel, A.: Airborne measurements of atmospheric aerosol particles and trace gases during photosmog episodes over the Swiss Plateau and the Southern Pre-Alpine Region, Atmos. Environ, 32, 20, 33813392, 1998.

Hogan, T. F. and Rosmond, T. E.: The description of the Navy operational global atmospheric prediction system's spectral forecast model, Mon. Wea. Rev., 119, 1786-1815, 1991.

Hogan, T. F. and Brody, L. R.: Sensitivity studies of the Navy's global forecast model parameterizations and evaluation of improvements to NOGAPS, Mon. Wea. Rev., 121, 2373-2395, 1993.

Kubilay, N., Nickovic, S., Moulin, C., and Dulac, F.: An illustration of the transport and deposition of mineral dust onto the eastern Mediterranean, Atmos. Environ, 34, 8, 1293-1303, 2000.

Israelevich, P. L., Levin, Z., Joseph, J. H., and Ganor, E.: Desert Aerosol Transport in the Mediterranean Region as Inferred from the TOMS Aerosol Index, J. Geophys. Res., 107, D21, 4572, doi:10.1029/2001JD002011, 2002.

McClain, C. R., Cleave, M. L., Feldman, G. C., Gregg, W. W., Hooker, S. B., and Kuring, N.: Science quality SeaWiFS data for global biosphere research, Sea Technol., 39, (9), 10-15, 1998.

Martin, R. V., Jacob, D. J., Logan, J. A., et al.: Interpretation of TOMS observations of tropical tropospheric ozone with a global model and in situ observation, J. Geophys. Res., 107, D18, 4351, doi: 10.1029/2001JD001480, 2002.

Moulin, C.: Atmospheric transport of African dust over the Mediterranean and the Atlantic: satellite climatology from METEOSAT Vis images (1983-1994) and relationship with climate, In French, Ph.D. thesis, Paris University, 246, 1997.

Moulin, C., Lambert, C. E., Dayan, U., Masson, V., Ramonet, M., Bousquet, P., Lagrand, M., Balkanski, Y. J., Guelle, W., Marticorena, B., Bergametti, G., and Dulac, F.: Satellite climatology of African dust transport in the Mediterranean atmosphere, J. Geophys. Res, 103, 13 137-13 144, 1998.

Nickovic, S., Kallos, G., Papadopoulos, A., and Kakaliagou, O.: A model for prediction of desert dust cycle in the atmosphere, J. Geophys. Res., 106, 18 113-18 130, 2001.
Penner, J. E., Andreae, M., Annegarn, H., Barrie, L., Feichter, J., Hegg, D., Jayaraman, A., Leaitch, R., Murphy, D., Nganga, J., and Pitari, G.: Aerosols, their Direct and Indirect Effects, Climate Change 2001: the Scientific basis, Contribution of Working Group 1 to the Third Assessment Report of Intergovernmental Panel on Climate Change, edited by Houghton, J. T., Ding, Y., Griggs, D. J., Noguer, M., van der Linden, P. J., Dai, X., Maskell, K., and Johnson, C. A., Cambridge Univ. press, Cambridge, UK and New York, NY USA, 881, 2001.

Prospero, J. M.: Long-term measurements of the transport of African mineral dust to the southeastern United States: implications for regional air quality, J. Geophys. Res, 104, $15917-$ 15927, 1999.

Prospero, J. M., Schmitt, R., Cuevas, E., Savoie, D. L., Graustein, W. C., Turekian, K. K., Volz-Thomas, A., Diaz, A., Oltmans, S. J., and Levy II, H.: Temporal variability of summer-time ozone and aerosol in the free troposphere over the eastern North Atlantic, Geophys. Res. Lett., 22, 21, 2925-2928, 1995.

Prospero, J. M., Ginoux, P., Torres, O., Nicholson, S. E., and Gill, T. E.: Environmental characterization of global sources of atmospheric soil dust identified with the Nimbus 7 Total Ozone Mapping Spectrometer (TOMS) absorbing aerosol product, Rev. Geophys., 40, 1002, doi:10.1029/2000RG000095, 2002.

Raes, F., Van Dingenen, R., Vignati, E., Wilson, J., and Putaud, J. F.: Formation and cycling of aerosol in the global troposphere, Atmos. Environ., 34, 25, 4215-4240, 2000.

de Reus, M., Dentener, F., Thomas, A., Borrmann, S., Stom, J., and Lelieveld, J.: Airborne Observations of Dust Aerosol over the North Atlantic Ocean During ACE 2: Indications for Heterogeneous Ozone Destruction, J. Geophys. Res., 105, D12, $15263-$ 15 276, doi:10.1029/2000JD900164, 2000.

Rodriguez, S., Querol, X., Alastuey, A., Kallos, G., and Kakaliagou, O.: Saharan dust contribution to $\mathrm{PM}_{10}$ and TSP levels in Southern and Eastern Spain, Atmos. Environ., 34, 25, 4215-4240, 2001.

Sancho, P., de la Cruz, J., Diaz, A., Martin, F., Hernandez, E., Valero, F., and Albarran, B.: A five-years climatology of backtrajectories from the Izana baseline station, Tenerife, Canary Islands, Atmos. Environ., 26, 1081-1096, 1992.

Schmitt, R. and Schreiber, B.: Effect of long-range transport on atmospheric trace constituents at the baseline station Tenerife $(\mathrm{Ca}-$ nary Islands), J. Atmos. Chem., 1, 335-351, 1998.

Schütz, L.: Long range transport of desert dust with special emphasis on the Sahara, Ann. N. Y. Acad. Sci., 338, 15-20, 1980.

Schwikowski, M., Seibert, P., Baltensberger, U., and Gäggeler, H. W.: A study of an outstanding saharan dust event at the high-alpine site Jungfraujoch, Switzerland, Atmos. Environ., 29, 1829-1842, 1995.

Sebald, L., Treffeisen R., Reimer, E., and Hies, T.: Spectral analysis of air pollutants, Part 2: ozone time series, Atmos. Environ., 34, 3503-3509, 2000.

Seibert, P., Kromp-Kolb, H., Baltensberger, U., Jost, D. T., and Schwikowski, M.: Trajectory analysis of high-alpine air pollution data, Air Pollution Modelling and its Application X, edited by Gryning, S. E. and Millian, M. M., 595-596, Plenum Press, New York, 1994.

Sokolik, I. N. and Toon, O. B.: Direct radiative forcing by anthropogenic airborne mineral aerosols, Nature, 381, 681-683, 1996.

Stohl, A.: Trajectory statistics - A new method to establish source- 
receptor relationship of air pollutants and its application to the transport of particulate sulfate in Europe, Atmos. Environ., 30, 579-587, 1996.

Stohl, A.: Computation, accuracy and applications of trajectories a review and bibliography, Atmos. Environ., 32, 947-966, 1998.

Stohl, A., Wotawa, G., Seibert, P., and Kromp-Kolb, H.: Interpolation errors in wind fields as a function of spatial and temporal resolution and their impact on different types of kinematic trajectories, J. Appl. Meteorol., 34, 2149-2165, 1995.

Torres, O., Bhartia, P. K., Herman, J. R., Ahmad, Z., and Gleason, K.: Derivation of aerosol properties from satellite measurements of backscattered ultraviolet radiation: theoretical basis, J. Geophys. Res., 103, 17 099-17 110, 1998.

Torres, O., Bhartia, P. K., Herman, J. R., Sinyuk, A., Ginoux, P., and Holben, B.: A long-term record of aerosol optical depth from TOMS observation and comparison to AERONET measurements, J. Atmos. Sci., 59, 398-413, 2002.

Van Dingenen, R., Putaud, J. P., Roselli, D., Dell'Acqua, A., Perrone, M. G., Bonasoni, P., and Facchini, M. C.: Aerosol properties at Monte Cimone (Italy) during and outside a saharan Dust transport event, A changing atmosphere, Proceedings of the 8th
European Symposium on the Physico-Chemical behaviour of Atmospheric Pollutants, edited by Hjorth, J., Raes, F., and Angeletti, G., Torino, Italy, 2001.

Vukovich, F. M.: Time scale of surface ozone variations in the regional non-urban environment, Atmos. Environ., 31, 1513-1530, 1997.

Weischet, W.: Introduction to General Climatology: Physical and Meteorological Basics, Vol. 1, Teubert Verlag, Stuttgart, 1977.

Wotawa, G. and Kröger, H.: Testing the ability of trajectory statistics to reproduce emission inventories of air pollutants in cases of negligible measurement and transport errors, Atmos. Environ., 33, 3037-3043, 1999.

Wotawa, G., Kröger, H., and Stohl, A.: Horizontal ozone transports towards the Alps - results from trajectory analyses and photochemical model studies, Atmos. Environ., 34, 1367-1377, 2000.

Zhang, Y., Sunwoo, Y., Kotamarthi, V., and Carmichael, G. R.: Photochemical oxidant pro-processes in the presence of dust: An evaluation of the impact of dust on particulate nitrate and processes ozone formation, J. Appl. Met., 33, 813-824, 1994.

Zurbenko, I. G.: The spectral analysis of time series, NorthHolland, Amsterdam, 1986. 